\title{
Comparison of Knowledge and Attitude Towards Orthodontic Treatment Among High School Students
}

\author{
Dr Jyoti Dhakal,' Dr Manish Shrestha, ${ }^{2}$ Dr Meenu Shrestha,3 Dr Asal Acharya ${ }^{4}$ \\ 'Assisstant Professor, ${ }^{2}$ Intern, Department of Orthodontics, Kantipur Dental College \\ ${ }^{3}$ Dental Surgeon, ${ }^{4}$ Orthodontist
}

\section{ABSTRACT}

Introduction: Adolescence is the time when a person attains awareness including the self-awareness about his/her health. Hence if proper knowledge is instilled during this time, it will be effective and good oral health behavior can last lifetime. The aim of this study was to assess knowledge and attitude towards orthodontic treatment among the students of public and private schools and compare between them.

Materials \& Method: A descriptive cross-sectional questionnaire-based study was performed among 700 students (350 from private and 350 from government schools around Kathmandu valley) of grade 8-10. Questionnaire consisted of 14 questions about knowledge and 10 questions about attitude relating to orthodontic treatment. Each response as "yes" was given score ' 1 ' and responses "no" and "don't know" were given score '0'. Total score was calculated, followed by mean and compared between that of private and government schools and between genders.

Result: No significant difference was found in the knowledge between the students of private and government schools. The difference in attitude score was found to be statistically significant $(p=0.00) .54 .29 \%$ of participants had never heard of an orthodontists, $48.57 \%$ never thought that crooked teeth have ill effects, and around $50 \%$ of participants were not aware that orthodontic treatment would improve the facial appearance. $47 \%$ of participants would not undergo treatment if it took $1-2$ years, $53 \%$ would not agree for extractions and $42 \%$ were not willing to wear retainers.

Conclusion: The knowledge and attitude level on orthodontics can be improved by incorporating the basic aspects of oral health in the syllabus of school education.

Keywords: Adolescence, Attitude, Knowledge, Malocclusion, Orthodontist.

\section{INTRODUCTION}

Oral health is an integral part of general health of the human being. One of the most common dental problems effecting the oral health is malocclusion.' Furthermore, malocclusion can result in social embarrassment, rejection and inevitable psychological disorders. ${ }^{2}$ In a developing country like Nepal greater fractions of younger populations are unaware of the causes, occurrence, prevention and consequences of malocclusion. Awareness is the state or ability to perceive, feel or to be conscious. Awareness forms the basis for practicing oral health which is an inseparable part of general health. ${ }^{3}$

Orthodontists have been giving more importance to impact of malocclusion on oral health and function in deciding the need of treatment. Lately, dental appearance and its effect on psychosocial wellbeing has been primary factors on determining the orthodontic treatment need as esthetics plays a vital role during pre-adolescent and adolescent phases. ${ }^{4}$ Being self-aware of malocclusion will ensure early treatment seeking behavior. If school children can be taught healthy lifestyle, this can be expected to last lifetime. ${ }^{3}$ If this leads to early treatment of malocclusion, it would lead to many benefits including prevention of consequences. From a patient's perspective, understanding the ill-effects of malocclusion can play vital role in planning of public health interventions. ${ }^{5}$

In a literature review, there are some studies assessing knowledge, attitude and practices (KAP) related to orthodontic treatment, 6,7 but there are not sufficient researches to assess the awareness of orthodontic treatment in school children. Hence, the objective of this study was to assess knowledge and attitude towards orthodontic treatment among the students of public and private schools and to compare between them. 


\section{MATERIALS AND METHOD}

Present study is a descriptive cross sectional study carried out among high school students at different government and private schools of Kathmandu, Nepal. The ethical approval was taken from Institutional Review Committee of Kantipur Dental College. The study was carried out during May 2018-September 2019. A written consent was taken from every participant of the study.

This is a questionnaire-based study, which was developed with the reference from different studies. 2,4,8 The questionnaire was first validated by doing pretest. The questionnaire comprised of three parts with a total of twenty four questions. First part included demographic details, second part contained 14 questions regarding knowledge about orthodontic treatment and third part contained 10 questions for evaluating attitude on orthodontic treatment.

Sample size was calculated using formula $4 \mathrm{pq} / \mathrm{l}^{2}$, where $p=0.73$ (prevalence of malocclusion among high school students in Kathmandu) ${ }^{9}, q=1-p=0.27$,
I = permissible error $=0.05$. Questionnaire was distributed to the respondents. Statistical analysis was done using SPSS version 21 software. Mean score of total knowledge and total attitude score were calculated. Mann-Whitney $U$ test was performed as the data were not normally distributed to test the difference between the mean scores of knowledge and attitude between the students of private and government schools. Significance level was set at $p \leq 0.05$.

\section{RESULT}

The study population comprised of 700 students (350 from private and 350 from government schools) of grade 8-10 at 5 private and government schools around Kathmandu valley. 324 of the students were male and 376 were female.

Table 1 and 2 show the response of the participants to the questions relating to orthodontic treatment knowledge and attitude. For each response as 'yes', 'I' score was given and for 'no' and 'don't know', '0' score was given. The individual scores were summed up to obtain the total score.

Table 1: Knowledge assessment of participants

\begin{tabular}{|c|c|c|c|c|c|}
\hline \multirow{2}{*}{ SN } & \multirow{2}{*}{ Questions on Knowledge } & \multirow{2}{*}{ Response } & \multicolumn{2}{|c|}{ Students/School } & \multirow{2}{*}{ Total } \\
\hline & & & Private & Government & \\
\hline \multirow{2}{*}{1} & \multirow{2}{*}{ Have you heard of an Orthodontist? } & Yes & 212 & 108 & $320(45.71 \%)$ \\
\hline & & No/don't know & $95 / 43$ & $142 / 100$ & $380(54.29 \%)$ \\
\hline \multirow{2}{*}{2} & \multirow{2}{*}{ Are you aware that orthodontist arrange irregular teeth? } & Yes & 216 & 230 & $446(63.71 \%)$ \\
\hline & & No/don't know & $63 / 71$ & $96 / 24$ & $254(36.29 \%)$ \\
\hline \multirow{2}{*}{3} & \multirow{2}{*}{ Have you heard about the irregularity of teeth? } & Yes & 297 & 262 & $559(79.86 \%)$ \\
\hline & & No/don't know & $32 / 21$ & $51 / 37$ & $141(20.14 \%)$ \\
\hline \multirow{2}{*}{4} & \multirow{2}{*}{ Have you noticed people having irregular teeth? } & Yes & 312 & 292 & $604(86.28 \%)$ \\
\hline & & No/don't know & $24 / 14$ & $43 / 15$ & $96(13.72 \%)$ \\
\hline \multirow{2}{*}{5} & \multirow{2}{*}{$\begin{array}{l}\text { Do you think heredity can influence the arrangement of } \\
\text { teeth? }\end{array}$} & Yes & 78 & 110 & $188(26.86 \%)$ \\
\hline & & No/don't know & $131 / 141$ & $121 / 119$ & $512(73.14 \%)$ \\
\hline \multirow{2}{*}{6} & \multirow{2}{*}{$\begin{array}{l}\text { Do you think habits like thumb sucking/tongue thrusting / } \\
\text { mouth breathing can cause irregularity of teeth? }\end{array}$} & Yes & 130 & 160 & $290(41.43 \%)$ \\
\hline & & No/don't know & $125 / 95$ & $128 / 62$ & $410(58.57 \%)$ \\
\hline \multirow{2}{*}{7} & \multirow{2}{*}{ Do you think irregular teeth can affect chewing ability? } & Yes & 249 & 242 & $491(70.14 \%)$ \\
\hline & & No/don't know & $56 / 45$ & $81 / 27$ & $209(29.86 \%)$ \\
\hline \multirow{2}{*}{8} & \multirow{2}{*}{ Do you think irregular teeth can affect speech? } & Yes & 202 & 190 & $392(56.00 \%)$ \\
\hline & & No/don't know & $105 / 43$ & $127 / 33$ & $308(44.00 \%)$ \\
\hline \multirow{2}{*}{9} & \multirow{2}{*}{ Do you think irregular teeth can affect oral hygiene? } & Yes & 199 & 240 & $439(62.71 \%)$ \\
\hline & & No/don't know & $77 / 74$ & $76 / 34$ & $261(37.28 \%)$ \\
\hline \multirow{2}{*}{10} & \multirow{2}{*}{$\begin{array}{l}\text { Do you think dental checkup and treatment of irregular- } \\
\text { ity is essential in early childhood and adolescent? }\end{array}$} & Yes & 301 & 272 & $573(81.86 \%)$ \\
\hline & & No/don't know & $25 / 24$ & $55 / 23$ & $127(18.14 \%)$ \\
\hline \multirow{2}{*}{11} & \multirow{2}{*}{ Do you know crooked teeth have ill effects? } & Yes & 116 & 244 & $360(51.43 \%)$ \\
\hline & & No/don't know & $77 / 157$ & $48 / 58$ & $340(48.57 \%)$ \\
\hline \multirow{2}{*}{12} & \multirow{2}{*}{ Have you seen people wearing braces? } & Yes & 337 & 297 & $634(90.57 \%)$ \\
\hline & & No/don't know & $8 / 5$ & $34 / 19$ & $66(9.43 \%)$ \\
\hline \multirow{2}{*}{13} & \multirow{2}{*}{$\begin{array}{l}\text { Did you know braces at the earlier age would improve } \\
\text { facial appearance? }\end{array}$} & Yes & 205 & 202 & $407(58.14 \%)$ \\
\hline & & No/don't know & $63 / 82$ & $86 / 62$ & $293(41.86 \%)$ \\
\hline 14 & Are you aware that few teeth may have to be removed & Yes & 154 & 198 & $352(50.29 \%)$ \\
\hline 14 & for aligning irregular teeth? & No/don't know & $85 / 111$ & $92 / 60$ & $348(49.71 \%)$ \\
\hline
\end{tabular}


Table 2: Attitude assessment of participants

\begin{tabular}{|c|c|c|c|c|c|}
\hline \multirow{2}{*}{ SN } & \multirow{2}{*}{ Questions on Attitude } & \multirow{2}{*}{ Response } & \multicolumn{2}{|c|}{ School } & \multirow{2}{*}{ Total } \\
\hline & & & Private & Government & \\
\hline \multirow{2}{*}{1} & \multirow{2}{*}{ Has anyone advised you to get your teeth aligned? } & Yes & 156 & 141 & $297(42.43 \%)$ \\
\hline & & No/don't know & $185 / 9$ & $180 / 29$ & $403(57.57 \%)$ \\
\hline \multirow{2}{*}{2} & \multirow{2}{*}{ Do you think irregular teeth can affect appearance? } & Yes & 240 & 174 & $414(59.14 \%)$ \\
\hline & & No/don't know & $59 / 51$ & $121 / 55$ & $286(40.86 \%)$ \\
\hline \multirow{2}{*}{3} & \multirow{2}{*}{$\begin{array}{l}\text { Do you believe teeth should be properly aligned for a } \\
\text { better facial appearance? }\end{array}$} & Yes & 275 & 259 & $534(76.29 \%)$ \\
\hline & & No/don't know & $39 / 36$ & $57 / 34$ & $166(23.71 \%)$ \\
\hline \multirow{2}{*}{4} & \multirow{2}{*}{ Have you ever felt the need to wear braces? } & Yes & 92 & 150 & 242 (34.57\%) \\
\hline & & No/don't know & $234 / 24$ & $181 / 19$ & $458(65.43 \%)$ \\
\hline \multirow{2}{*}{5} & \multirow{2}{*}{ Would you do orthodontic treatment if it takes 1-2 years? } & Yes & 143 & 225 & 368 (52.57\%) \\
\hline & & No/don't know & $105 / 102$ & $70 / 55$ & $332(47.43 \%)$ \\
\hline \multirow{2}{*}{6} & \multirow{2}{*}{$\begin{array}{l}\text { Will you agree, if some teeth have to be removed for } \\
\text { orthodontic treatment? }\end{array}$} & Yes & 113 & 215 & $328(46.86 \%)$ \\
\hline & & No/don't know & $187 / 50$ & $105 / 30$ & $372(53.14 \%)$ \\
\hline \multirow{2}{*}{7} & \multirow{2}{*}{$\begin{array}{l}\text { Will you wear additional retainer appliance for 6-12 } \\
\text { months after treatment completion? }\end{array}$} & Yes & 175 & 225 & 400 (57.14\%) \\
\hline & & No/don't know & $99 / 76$ & $86 / 39$ & $300(42.86 \%)$ \\
\hline \multirow{2}{*}{8} & \multirow{2}{*}{$\begin{array}{l}\text { Will you continue treatment if you experience slight pain, } \\
\text { ulcerations or discomfort? }\end{array}$} & Yes & 161 & 213 & $374(53.43 \%)$ \\
\hline & & No/don't know & $105 / 84$ & $96 / 41$ & $326(46.57 \%)$ \\
\hline \multirow[b]{2}{*}{9} & \multirow{2}{*}{ Do you know that orthodontic treatment is costly? } & Yes & 158 & 187 & $345(49.29 \%)$ \\
\hline & & No/don't know & $52 / 140$ & $93 / 70$ & $355(50.71 \%)$ \\
\hline \multirow{2}{*}{10} & \multirow{2}{*}{$\begin{array}{l}\text { Have you undergone any treatment for irregular teeth in } \\
\text { the past? }\end{array}$} & Yes & 53 & 31 & $84(12.00 \%)$ \\
\hline & & No/don't know & $276 / 21$ & $291 / 28$ & $616(88.00 \%)$ \\
\hline \multirow{2}{*}{$10 a$} & \multirow{2}{*}{ Was the treatment completed as planned? } & Yes & 35 & 17 & 52 (61.90\%) \\
\hline & & No/don't know & $11 / 7$ & $9 / 5$ & $32(38.10 \%)$ \\
\hline \multirow{2}{*}{$10 \mathrm{~b}$} & \multirow{2}{*}{$\begin{array}{l}\text { Did you wear retainer for the entire duration specified by } \\
\text { your doctor? }\end{array}$} & Yes & 10 & 11 & $21(25.00 \%)$ \\
\hline & & No/don't know & $20 / 23$ & $10 / 10$ & $63(75.00 \%)$ \\
\hline \multirow{2}{*}{$10 c$} & \multirow{2}{*}{$\begin{array}{l}\text { Did you consult your doctor for any complaints after } \\
\text { completion of treatment? }\end{array}$} & Yes & 31 & 17 & $48(57.14 \%)$ \\
\hline & & No/don't know & $10 / 12$ & $8 / 6$ & $36(42.86 \%)$ \\
\hline
\end{tabular}

10a, 10b and 10c questions were only considered if the response to question 10 was 'yes'.

Table 3: Comparison of knowledge and attitude according to type of school

\begin{tabular}{|c|c|c|c|c|c|}
\hline \multicolumn{2}{|c|}{ Type of school } & $\mathbf{N}$ & Mean Score & Mean rank & $p$ value \\
\hline \multirow{2}{*}{ Knowledge } & Private & 350 & $8.59 \pm 2.44$ & 339.32 & \multirow{2}{*}{0.14 (NS) } \\
\hline & Government & 350 & $8.71 \pm 2.84$ & 361.68 & \\
\hline \multirow{2}{*}{ Attitude } & Private & 350 & $4.47 \pm 1.96$ & 319.44 & \multirow{2}{*}{$0.00(S)$} \\
\hline & Government & 350 & $5.20 \pm 2.54$ & 381.56 & \\
\hline
\end{tabular}

NS, Not significant; S, Significant

Table 4: Comparison of knowledge and attitude according to gender

\begin{tabular}{|l|c|c|c|c|c|}
\hline \multicolumn{2}{|c|}{ Gender } & N & Mean Score & Mean rank & p value \\
\hline \multirow{2}{*}{ Knowledge } & Male & 324 & $8.36 \pm 2.62$ & 326.09 & 0.003 (S) \\
\cline { 2 - 6 } & Female & 376 & $8.90 \pm 2.64$ & 371.53 & \multirow{2}{*}{0.85 (NS) } \\
\hline \multirow{2}{*}{ Attitude } & Male & 324 & $4.81 \pm 2.35$ & 349.02 & 351.77 \\
\cline { 2 - 6 }
\end{tabular}

The mean knowledge and attitude score were calculated and compared between the students of private and government schools (table 3) and between the gender (table 4).

Mean score of knowledge among students of private and government schools were 8.59 \pm 2.44 and $8.71 \pm 2.84$, respectively. No significant difference was found between the knowledge among the students of private and government schools. Mean score of attitude among the students of private and government schools were $4.47 \pm 1.96$ and $5.20 \pm 2.54$ respectively. The difference in attitude score was found to be statistically significant $(p=.00)$.

Mean score of knowledge among males and females were $8.36 \pm 2.62$ and $8.90 \pm 2.64$, respectively. The differences was found to be statistically significant $(p=.003)$. Mean score of attitude among males and females were $4.81 \pm 2.35$ and $4.86 \pm 2.25$, respectively. The difference was not statistically significant. 


\section{DISCUSSION}

The present study found that $54.29 \%$ of participants have never heard of an orthodontists, $48.57 \%$ never realized that crooked teeth have ill effects and around $50 \%$ of participants were not aware that orthodontic treatment would improve facial appearance or the treatment requires removal of teeth sometimes. Around $58 \%$ did not think that adverse habits cause malocclusion, $30 \%$ thought that malocclusion do not affect chewing ability, $44 \%$ thought that malocclusion do not affect speech and around $37 \%$ thought that malocclusion do not affect oral hygiene.

Around $47 \%$ of participants would not undergo treatment if it extends for $1-2$ years, $53 \%$ would not agree for extractions and $42 \%$ would not wear retainers. $12 \%$ of total participants (84) have undergone orthodontic treatment, out of which around $62 \%$ (52) said the treatment was completed according to the plan, $25 \%$ (21) wore retainers as specified by the doctor and around $57 \%$ (48) went for post treatment follow up.

Mean score of knowledge and attitude of students of private and government schools was found to be just above 50 percent of total knowledge score that could be obtained. This signifies need for improvement in orthodontic treatment knowledge among high school students. The improved level of orthodontic treatment knowledge will help in attainment of good oral health of teenagers which will be beneficial for improving quality of life.

There was no any significant difference between the mean score of knowledge among students of private and government schools. Mean score of attitude was found to be statistically higher in students of government school compared to those of private school. Students of government school though having similar level of knowledge were found to be exposed more towards orthodontic treatment and its aspect.

Roopa Siddegowda ${ }^{3}$ showed that high school and middle school students have similar level of orthodontic treatment compared to the result of this study. This might be because of similar sample characteristics in these studies.

In contrast to the result of the present study, study done by Essamet and Darout ${ }^{10}$ showed higher level of orthodontic treatment knowledge among students of Jazan university. This higher level of awareness was found because sample comprised students of higher age as compared to sample of present study. And the sample also comprised students from medical and health sciences field.

Zakirulla et $\left.a\right|^{8}$ concluded though there is a positive awareness towards orthodontic treatment among school children, but specific misconceptions and barrier exist. The result of present study also showed level of knowledge and attitude of school children towards orthodontic treatment should be increased.

Study done on dental students and dental surgeons ${ }^{11}$ showed dental students had good knowledge about the orthodontic treatment and had a positive attitude towards it. This result cannot be compared to the result of the present study as the sample population differs vastly in these two studies. Sample population of the previous article comprises students who are already exposed to malocclusion and orthodontics in their study in contrast to the sample population of the present study.

\section{CONCLUSION}

The level of orthodontic treatment knowledge and attitude of high school students assessed in this study was found to be just above $50 \%$ of the total score. The knowledge and attitude level can be improved by incorporating basic aspects of oral health in the syllabus of school education. If we can instill good oral health behavior during adolescence, it's most likely to last lifelong.

\section{Acknowledgement}

We would like to express our gratitude towards Dr Sujita Shrestha, faculty, Department of Community Dentistry, Kantipur Dental College for support regarding statistical analysis.

We would also like to express our gratitude towards Prof. Dr Rabindra Man Shrestha, Dr Ujjwal Pyakurel, Dr Alka Gupta, faculties, Department of Orthodontics, Kantipur Dental College for their valuable contribution in manuscript writing. 


\section{REFERENCES}

1. Dhar V, Jain A, Van Dyke TE, Kohli A. Prevalence of gingival diseases, malocclusion and fluorosis in school-going children of rural areas in Udaipur district. J Indian Soc Pedod Prev Dent. 2007;25(2):103-15.

2. Acharya A, Mishra P, Shrestha RM, Shah P. Orthodontic treatment knowledge among general dentists and non-orthodontic specialists. Orthod J Nepal. 2019:9(1):39-43.

3. Siddegowda R. An epidemiological survey on the awareness towards orthodontic treatment among middle school and high school children of Karnataka state. J Cell Sci Ther. 2015;6(4):10-2.

4. Shekar S, Chandrashekar BR, Bhagyalakshmi A, Avinash BS, Girish MS. Knowledge, attitude, and practices related to orthodontic treatment among college students in rural and urban areas of Mysore, India : A cross-sectional questionnaire study. Indian J Oral Heal Res. 2017:3(1):9-14.

5. Choi S, Kim B, Cha J, Hwang C. Impact of malocclusion and common oral diseases on oral health-related quality of life in young adults. Am J Orthod Dentofac Orthop. 2015;147(5):587-95.

6. Shrestha RM, Bhattarai P, Dhakal J, Shrestha S. Knowledge, attitude and practice of patients towards orthodontic treatment: A multicentric study. Orthod J Nepal. 2014;4(1):6-11.

7. Shrestha RM, Shrestha S. Perception and practice of Nepalese adult and adolescent patients towards orthodontic treatment. Orthod J Nepal. 2015;5(1):7-11.

8. Zakirulla M, Almubarak H, Fageeh SN, Alghothimi AA, Alqahtani SK, Alqahtani FM, et al. Awareness and behaviour related to orthodontic treatment among school children in Aseer region, Kingdom of Saudi Arabia. Open J Stomatol. 2019;9:87-94.

9. Shrestha BK, Yadav R, Basel P. Prevalence of malocclusion among high school students in Kathmandu valley. Orthod Jounal Nepal. 2012;2(1):1-5.

10. Essamet M, Darout IA. Awareness and behavior related to orthodontic treatment among Jazan University students, Kingdom of Saudi Arabia. 2016:8(3):12-7.

11. Agrawal R. Knowledge, attitude and perception of orthodontic treatment among dental students. Int J Dent Res. 2018;6(1):3-5. 